\title{
Pelatihan Pembuatan Hand Sanitizer, Sabun Cair, dan Disinfektan bagi Ibu PKK
}

\author{
Mutia Lina Dewi*, Qomariah dan Wahyu Ningsih \\ Jurusan Teknik Sipil, Politeknik Negeri Malang, Jl. Soekarno Hatta 9 Malang, Indonesia-65156 \\ Correspondence: mulinde13@gmail.com \\ Received: 30 Juni 2021 - Revised: 01 Agustus 2021 - Accepted: 16 Agustus 2021
}

\begin{abstract}
Abstrak. Wabah Covid-19 telah melanda secara global hampir dua tahun dengan banyak korban. Belum ada tanda-tanda berakhir, bahkan semakin meningkat. Kini semuanya berubah, tidak ada lagi silaturahmi saling mengunjungi, tidak ada lagi pembelajaran di kelas, semuanya dilakukan secara virtual. Menjaga kesehatan menjadi hal utama, wajib menerapkan protokol kesehatan. Pemerintah gencar mencanangkan program 3M, memakai masker, mencuci tangan, dan menjaga jarak. Kebutuhan penunjang protokol kesehatan sempat sulit di pasaran, kalaupun ada harganya melangit. Seiring dengan meningkatkan wabah Covid-19, kebutuhan alat protokol kesehatan semakin meningkat. Hand sanitizer, sabun cuci tangan, dan disinfektan menjadi kebutuhan utama. Ibu-ibu mengharapkan keterampilan membuat sendiri penunjang protokol kesehatan. Secara kebetulan, di perumahan Joyo Grand Malang ada salah ibu berbisnis di masa pandemi dengan memproduksi kebutuhan protokol kesehatan, seperti hand sanitizer dan sabun cuci tangan. Tujuan PKM adalah menambah wawasan keterampilan ibu PKK di lingkungan Perumahan Joyo Grand Malang dengan memberi pelatihan pembuatan penunjang protokol kesehatan. Manfaat yang diharapkan ibu PKK adalah dapat menghemat pengeluaran dan dapat mempunyai income atau pendapatan sendiri. Hasil kegiatan diperoleh peserta senang dan antusias mengikuti pelatihan pembuatan hand sanitizer, sabun cair, dan disinfektan. Peserta berharap ada pelatihan sejenis yang bermanfaat bagi kehidupan sehari-hari dan ada peluang menambah pendapatan.
\end{abstract}

Kata kunci: pelatihan, wawasan, pendapatan, protokol kesehatan

Citation Format: Dewi, M.L., Qomariah \& Ningsih, W. (2021). Pelatihan Pembuatan Hand Sanitizer, Sabun Cair, dan Disinfektan bagi Ibu PKK. Prosiding Seminar Nasional Abdimas Ma Chung (SENAM), 240-248. 


\section{PENDAHULUAN}

Awal Maret 2020 lalu wabah Covid-19 mulai menelan korban, di luar perkiraan banyak orang juga para ahli kesehatan virus semakin berkembang semakin banyak korban. Update Kabar siang TV-One per tanggal 30 Juli 2021 di Indonesia ada 3.372.374 orang terpapar positif Covid-19, sembuh 2.730 .720 orang, dan meninggal 92.311 orang. Suatu jumlah yang sangat banyak, ujian terberat bagi umat manusia di seluruh dunia. Pemerintah sedang berupaya memutus rantai penyebaran dengan pemberian vaksin secara gratis. Juga gencar mencanangkan protokol kesehatan dengan program $3 \mathrm{M}$, memakai masker, mencuci tangan, dan menjaga jarak. Protokol kesehatan adalah aturan dan ketentuan yang perlu diikuti oleh segala pihak agar dapat beraktivitas secara aman pada masa pandemi Covid19.

Dibalik musibah selalu ada hikmah. Akibat para ibu sering di rumah saja, kini banyak ibu berwirausaha menghasilkan income atau pendapatan. Mulai dari makanan, minuman, tanaman, sampai barang pecah belah. Ibu Diah Yuaningsih atau lebih dikenal dengan ibu Efendi mempunyai usaha baru di masa pandemi, yaitu memproduksi hand sanitizer dan sabun cair cuci tangan. Ibu Efendi lebih tepat sebagai marketing, dikarenakan yang membeli bahan dan mengolahnya menjadi alat protokol kesehatan adalah putrinya bernama Anggraeni Puspita Sari mahasiswi tingkat akhir Jurusan Teknik Kimia Politeknik Negeri Malang. Berawal dari tugas mata kuliah Kewirausahaan untuk menjual suatu produk yang berkaitan dengan latar belakang pendidikan. Sesuai dengan kebutuhan masyarakat masa kini, Anggraeni membuat dan menjual hand sanitizer di lingkungan ibu PKK perumahan Joyo Grand. Seiring dengan keberadaan covid-19 usahanya telah berkembang dengan memproduksi kebutuhan lain, yaitu sabun cair untuk cuci tangan dengan label SmurfLab.

Tujuan kegiatan pengabdian masyarakat adalah menambah wawasan keterampilan ibu PKK di lingkungan Perumahan Joyo Grand Malang dengan memberi pelatihan pembuatan penunjang protokol kesehatan. Manfaat yang diharapkan ibu PKK adalah dapat menghemat pengeluaran dan dapat mempunyai income atau pendapatan sendiri.

\section{MASALAH}

Pada Permasalahan mitra adalah semakin meningkatnya kebutuhan penunjang protokol kesehatan, seperti hand sanitizer, disinfektan, dan sabun cuci tangan. Hal ini dikarenakan semakin meningkatnya wabah covid-19. Ibu PKK membutuhkan keterampilan 
pembuatan hand sanitizer, sabun cair, dan disinfektan. Menurut Amanda (2020), virus tidak kasat mata, sebaiknya tetap melakukan upaya pencegahan dengan menyemprotkan disinfektan setelah bersih-bersih.

\section{METODE PELAKSANAAN}

1. Khalayak Sasaran

Khalayak sasaran adalah ibu PKK Dawis (dasa wisma) RT 06 RW 08 lingkungan Joyo Grand yang pada setiap pertemuan bulanan diupayakan ada kegiatan yang bermanfaat, tidak hanya arisan saja tetapi ada kegiatan lain yang sangat berguna bagi ibu PKK.

2. Metode PKM

Metode kegiatan adalah pemberian pelatihan dengan narasumber warga sendiri yang mempunyai usaha SmurfLab. Prosedur kegiatan diuraikan dengan langkah-langkah sebagai berikut.

a. Koordinasi dengan Ketua PKK RT 06 dan narasumber.

b. Penyusunan proposal

c. Pembelian bahan-bahan protokol kesehatan beserta kelengkapannya

d. Pelaksanaan pelatihan dan pemasaran hand sanitizer, disinfektan, dan sabun cair untuk cuci tangan.

e. Desiminasi pada Seminar Nasional ber-ISSN

f. Pelaporan kegiatan PPM

Pada pelaksanaan pelatihan ini sesuai protokol kesehatanpandemi covid-19, memakai masker, jaga jarak, dan menggunakan hand sanitizer sebelum masuk ruangan Balai RT 06. Selain itu, setiap peserta diberikan hasil pelatihan dan konsumsi. Konsumsi juga menyesuaikan pandemi, tidak dimakan di lokasi PKM, tetapi dibawa pulang.

3. Rancangan Evaluasi

Untuk melihat keberhasilan pengabdian ini dilakukan pengamatan berdasarkan catatan di lapangan, sehingga dapat menjawab pertanyaan seperti berikut. Apakah PKM ini bermanfaat bagi ibu PKK?

\section{HASIL DAN PEMBAHASAN}

\section{Hasil Kegiatan PKM}

Kegiatan pengabdian kepada masyarakat ini dilaksanakan pada hari Senin tanggal 7 Juni 2021 di Balai RT 06 RW 08 perumahan Joyo Grand Malang. Dihadiri 16 ibu dari 
18 anggota Dawis, sehingga ada 2 ibu yang tidak hadir. Narasumber kegiatan ini adalah ananda pemilik SmurfLab, yaitu Anggraeni Puspita Sari mahasiswi tingkat akhir Jurusan Teknik Kimia Politeknik Negeri Malang. Gambar 1 berikut menunjukkan kegiatan PKM.

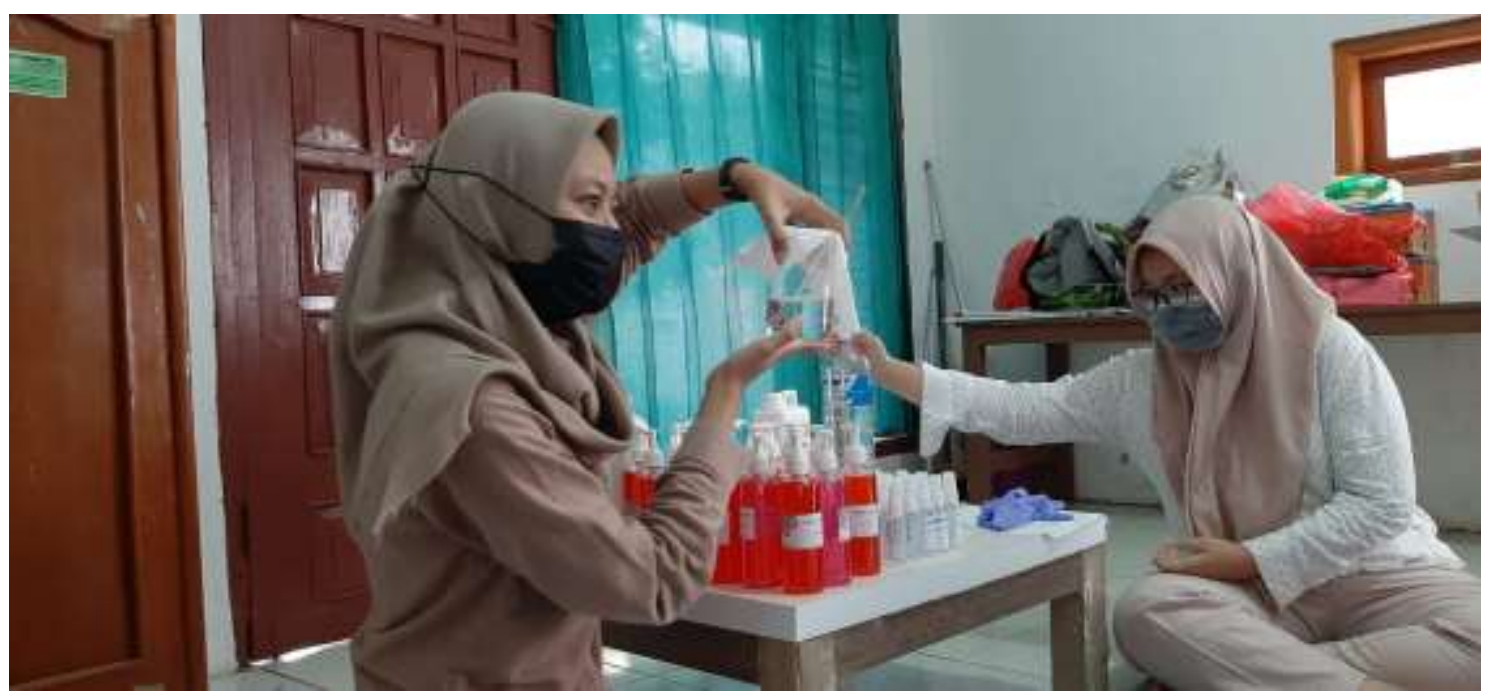

Gambar 1a. Narasumber menjelaskan pembuatan hand sanitizer

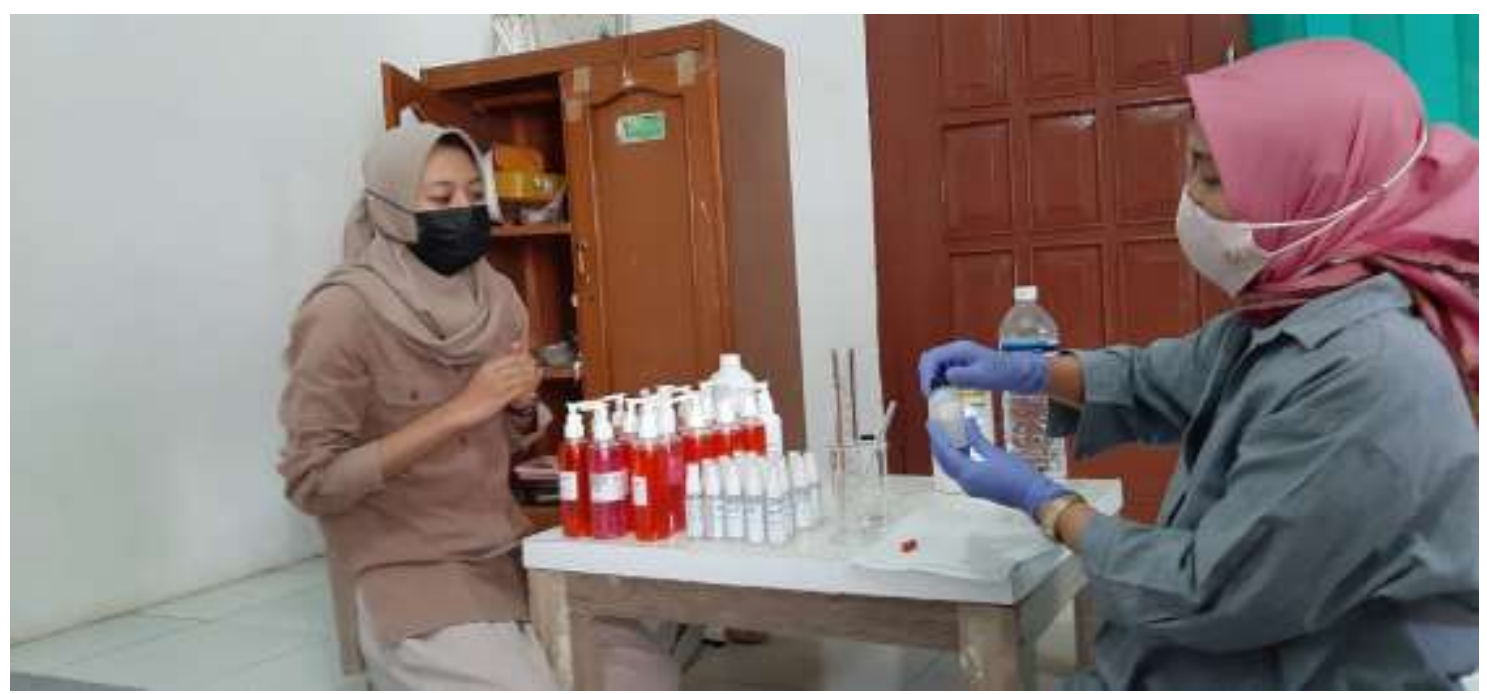

Gambar 1b. Narasumber meminta peserta membantu meracik bahan hand sanitizer 


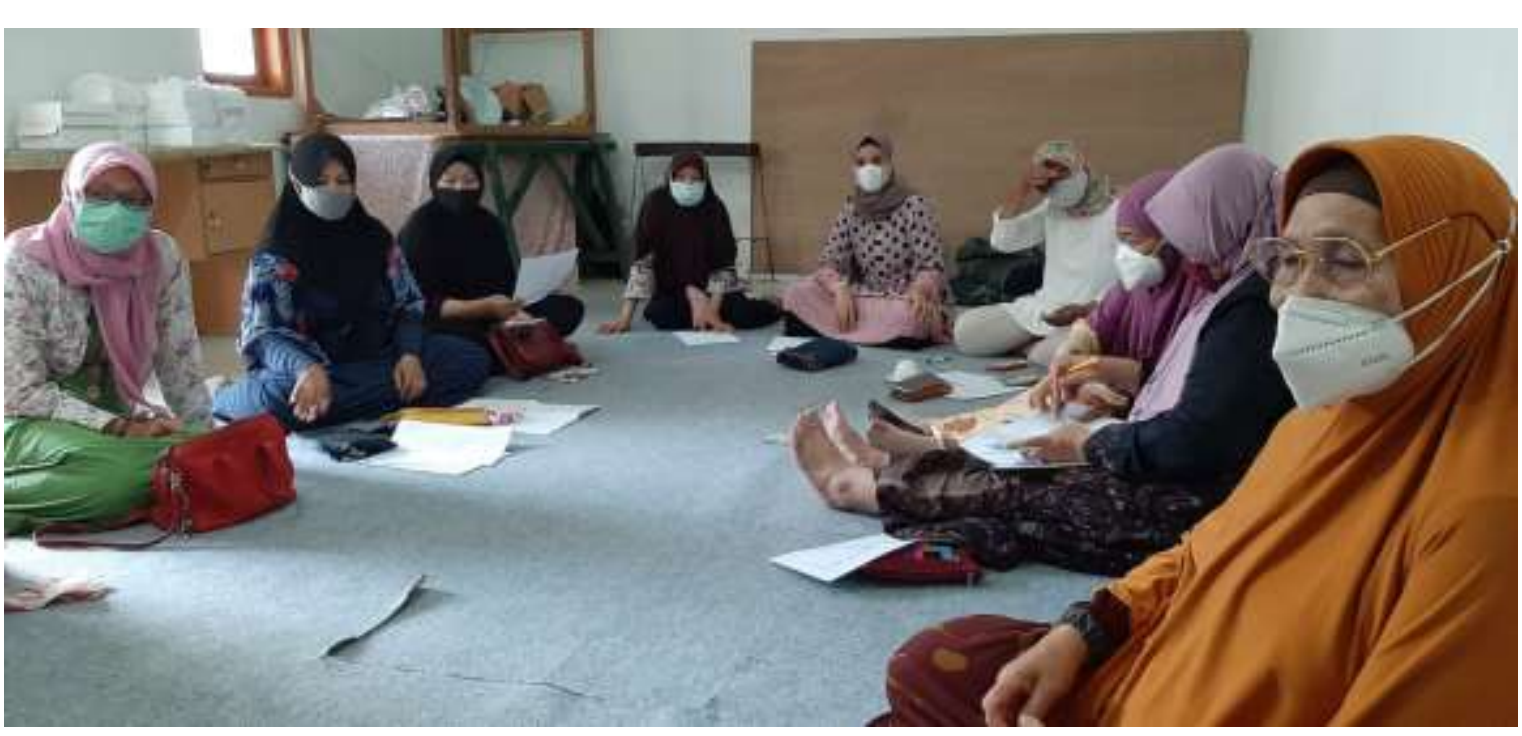

Gambar 1c. Ibu PKK menyimak penjelasan narasumber

\section{Pembahasaan}

Pelaksanaan kegiatan pengabdian kepada masyarakat ini diadakan pada hari Senin 7 Juni 2021 sore hari setelah shalat ashar. Hal ini disesuaikan dengan kesepakatan dalam keadaan masa pandemi Covid-19. Tidak digabung dengan agenda arisan dikarenakan keterbatasan waktu. Pelaksanaan sesuai protokol kesehatan, pakai masker dan jaga jarak. Untuk menyingkat waktu demo hanya pembuatan hand sanitizer, yang lainnya telah dipersiapkan narasumber, peserta diberi materi bahan dan cara pembuatan. Menurut Utomo (2020), meyatakan pelatihan pembuatan hand sanitizer berdampak positif terhadap lingkungan SMK Negeri 4 Surabaya, perubahan ini terlihat dari protokol kesehatan yang berlaku di sekolah, serta dari segi ekonomi dapat menekan alokasi dana untuk pembelian produk hand sanitizer.

Narasumber memberikan materi sangat baik, komunatif, dan menyenangkan. Narasumber meminta satu peserta untuk membantu meracik bahan sesuai takaran, dengan demikian peserta praktek langsung membuat hand sanitizer. Selain itu, peserta diperbolehkan langsung bertanya, jika ada hal yang kurang jelas. Setiap peserta diberi materi pelatihan berupa foto copy alat, bahan dan proses pembuatan hand sanitizer, sabun cair, dan disinfektan.

Karena keterbatasan waktu dan suasana pandemi covid-19 praktek pembiatan hanya hand sanitizer saja, lainnya diberikan dalam bentuk foto copyan bahan, alat, dan cara kerja. Bahan utama pembuatan hand sanitizer adalah alkohol. Menurut Ningsih (2019) 
alkohol dalam hal ini etanol sudah biasa dijadikan sebagai antibakteri maupun desinfektan sehingga pasti memberikan kontribusi pembentukan zona hambat pada kontrol positif.

Materi pelatihan adalah sebagai berikut.

1. Pembuatan Hand Sanitizer

Alat :

- Gelas ukur $100 \mathrm{ml}$

- Panci + tutup steril

- Batang pengaduk

- Botol semprot

Bahan :

- Etanol 96\%

- Gliserol 98\%

- Hidrogen peroksida 3\%

- Aquadest

Langkah Kerja :

1. $833 \mathrm{ml}$ etanol $96 \%$ dimasukkan ke dalam panci bertutup.

2. Tambahkan $41,7 \mathrm{ml}$ hidrogen peroksida $3 \%$ ke dalam panci berisi etanol.

3. Tambahkan $14,5 \mathrm{ml}$ gliserol $98 \%$. Tambahkan air hingga total bahan berjumlah $1000 \mathrm{ml}$, aduk hingga homogen.

4. Kemas larutan ke dalam botol semprot.

5. Simpan selama 72 jam untuk memastikan tidak ada kontaminasi organisme.

6. Handsanitizer siap digunakan.

2. Pembuatan Sabun Cuci Tangan

Alat:

- Timbangan

- Wadah/Ember 1 liter

- Erlen meyer $500 \mathrm{ml}$

- Pengaduk

- Tempat penampung (botol, jirigen, dan lainnya)

Bahan:

- Emal 70C $18 \%$ 
- Alkopal N100

- Larutan garam

- EDTA2Na

- Air

- Parfum

- Pewarna
$1 \%$

$20 \%, 18 \%$ (40 gr air: 160 gr garam)

$0,4 \%$ (tidak harus ada)

$62,2 \%$

$0,4 \%$

secukupnya

Langkah Kerja:

1. Timbang bahan - bahan sesuai kebutuhan, lalu tempatkan dalam wadah yang telah di sediakan.

2. Masukkan air sekitar $2 / 3$ bagian ke dalam wadah (sisanya untuk membilas)

3. Masukkan pewarna ke dalam wadah (sebelumnya larutkan pewarna dengan sedikit sisa air), aduk hingga larut semua.

4. Masukkan EDTA2Na ke dalam wadah (sebelumnya larutkan terlebih dahulu dengan sedikit sisa air), aduk hingga larut semua.

5. Masukkan Emal-70C, bilas sisa Emal-70 C dengan sisa air, kemudian masukkan ke dalam wadah. Aduk hingga larut semua.

6. Masukkan alkopal N 100. Bilas dengan sisa air, kemudian masukkan ke dalam wadah, aduk hingga larut semua.

7. Masukkan larutan garam secara perlahan. Aduk hingga terbentuk larutan kental.

8. Masukkan parfum ke dalam wadah, aduk hingga larut semua.

9. Diamkan produk hingga busa yang terbentuk berkurang.

3. Pembuatan Disinfektan

Alat:

- Botol semprot

- Gelas ukur

- Ember

- Sarung tangan sekali pakai

Bahan :

- 2 sendok makan $(30 \mathrm{ml})$ cairan pemutih pakaian, untuk 1 liter air

- Air bersih

Langkah Kerja : 
1. Tuang cairan pemutih pakaian secara hati-hati ke dalam ember. Lalu, tambahkan air bersih dan aduk hingga tercampur dengan merata.

2. Apabila larutan cairan pemutih pakaian sudah tercampur sempurna, Anda bisa membagikan larutan cairan pemutih pakaian tersebut ke dalam botol semprot yang lebih kecil agar mudah digunakan.

3. Cairan disinfektan sudah siap digunakan.

Selama pelaksanaan berlangsung, pelaksana mengamati dan meminta pendapat peserta mengenai kegiatan PKM ini. Hasil yang diperoleh diuraikan sebagai berikut.

1. Ibu PKK sangat antusias mengikuti pelatihan yang sangat diperlukan pada masa pandemi ini.

2. Ibu PKK aktif bertanya dan senang dikarenakan menambah wawasan

3. Ibu PKK paling mudah dipraktekkan adalah pembuatan disinfektan yang bahannya mudah didapat, yaitu cairan pemutih pakaian dan air bersih.

4. Ibu PKK berharap ada pelatihan lanjutan yang bermanfaat bagi kehidupan seharihari

Pelaksanaan pelatihan ini telah dipublikasikan pada media sosial you tube tanggal 1 Agustus 2021 dengan link https://youtu.be/dSmQImtAZy8.

\section{KESIMPULAN}

Simpulan kegiatan PKM adalah pelatihan pembuatan penunjang protokol kesehatan menambah wawasan ibu PKK Dawis RT 06 RW 08 Joyo Grand Malang, peserta pelatihan senang dapat peluang berbisnis hand sanitizer, sabun cair, dan disinfektan, peserta berharap ada pelatihan sejenis yang bermanfaat bagi kehidupan sehari-hari dan menambah pendapatan.

\section{UCAPAN TERIMA KASIH}

Kami sampaikan terima kasih kepada tim reviewer P2M Politeknik Negeri Malang yang telakan meloloskan proposal Pengabdian Kepada Masyarakat ini sehingga dibiayai dana DIPA Politeknik Negeri Malang Nomor: SP DIPA - 023.18.2.677606/2021 tanggal 23 November 2020.

\section{DAFTAR PUSTAKA}

Amanda. 2020. https://hellosehat.com/hidup-sehat/kebersihan-diri/manfaat-disinfektanuntuk-kebersihan-rumah/\#gref 
Ningsih, dkk. 2019. Hand Sanitizer Ekstrak Metanol Daun Mangga Arumanis (Mangifera indica L.). ALCHEMY Jurnal Penelitian Kimia, Vol. 15(1) 2019, 10-23.

Universitas Sbelas Maret.

Utomo, dkk. 2020. Pelatihan Pembuatan Hand Sanitizer dan Aplikasi Pola Hidup Bersih di SMK Negeri 4 Surabaya dalam Menyikapi Pandemi Covid-19. Educivilia: Jurnal Pengabdian pada Masyarakat Universitas Djuanda. p-ISSN 2721-1541 | e-ISSN 2721-5113

Septiani. 2017. health.detik.com/berita-detikhealth/d-5096243/fungsi-hand-sanitizercegah-corona-hingga-timbulnya-jerawat

(C) 2021 by authors. Content on this article is licensed under a Creative Commons Attribution 4.0 International license. (http://creativecommons.org/licenses/by/4.0/). 